\title{
LEGAL PROTECTION OF WOMEN WITH DISABILITIES AS THE VICTIMS OF SEXUAL VIOLENCE IN YOGYAKARTA
}

\author{
Subekti; Dea Annisa \\ Faculty of Law, Universitas Sebelas Maret \\ Email: subektifhuns@gmail.com; deaannisa786@gmail.com
}

\begin{abstract}
The purpose of this research are to know the forms of legal protection to women with disabilities as victims of sexual violence in Yogyakarta and to know obstacles that occur in the legal protection process. This research is an empirical law research that is both descriptive by qualitative approaches. Location of the research at the CIQAL Foundation Yogyakarta. Based on the results of the research, it is got the data since 2014 until 2016, CIQAL has noted there were seventy six of violence cases against women with disabilities in Yogyakarta region and sixty cases there are sexual violence. From the sixty cases of sexual violence only three cases have got judicial process. Not processing of legal, cause of the victims can not get the justice and their rights as the victims and also the perpetrators of violence have potential to do the violence again. The matter CIQAL efforts to give the legal protection to women with disabilities as victims of sexual violence get their rights. The legal protection is given the legal colleague and the non-legal colleague by the CIQAL Foundation Yogyakarta. There are some obstacles when the foundation gives doing the legal protection process. The obstacles which are divided by two, internal victims factors that includes the limitation which owned the victims, and the victims family; external victims factors that includes the problem in the legal scope, and the society.
\end{abstract}

\section{Keywords : Legal protection, women with disabilities, victims of sexual violence.}

\section{A. INTRODUCTION}

The issues of people with disabilities in Indonesia is the issues which do not develop that turn people with disabilities is part from public society, which later undermine the principle of equality. The existence of people with disabilities is still ignored by several people in Indonesia, where people with disabilities are not considered as a citizens, even also are not considered as the real humans because it has the limited condition. The Law Number 8 of 2016 on People with Disabilities formulate the understanding of people with disabilities in Article 1 Paragraph 1, which states is "People with disabilities it is every human who has got physical, intellectual, mental and/or sensory limitation in a long periods which interact with the environment can get obstacles and difficulties to full participate and effectively with other citizens based on equal rights". reproduction in any medium, provided the original work is properly cited. 
People with disabilities as part of Indonesian have the same rights as citizens of non other disabilities. Article 27 Paragraph (1) the 1945 Constitution of The Republic of Indonesia explain the recognition of the principle of equality before the law all of citizens without exception and is treated with fairness and without difference. The principle of equality before the law to guarantee the justice for all every human without ignoring the background, include vulnerable groups especially people with disabilities.

Indonesia has taken important step itself to strengthen our commitment to develop and guarantee the protection of human rights of people with disabilities. The matter is showed up the rules which regulate specially matters with people with disabilities. The regulation is The Law Number 19 of 2016 on The Ratification of The Convention on the Rights of Person with Disabilities (CRPD) and The Law Number 8 of 2016 on People with Disabilities which replaces The Law Number 4 of 1997 on People with Physical Defect, which specifically regulates fulfillment of the rights of people with disabilities which replaces every individual of people with disabilities get guarantee of respect, protection, and fulfillment of human rights.

The legal protection of people with disabilities certainly it will relate fulfillment and protection of rights of people with disabilities in equal and fairness issues. The legal protection to people with disabilities is the most prominent is given because the people with disabilities suffer susceptibility. The susceptibility is stated clearly on Article $6 C R P D$ which states that people with disabilities specially women and girls with disabilities is susceptible to dual discrimination, and relating the state takes obligation steps to guarantee whole fulfillment of all human rights and fundamental freedoms.

Women with disabilities are often done to become discriminative object and violence against women, one of sexual violence is caused the suffering to them. The sexual violence is an important and complicated issues of all violence against women map.

Sexual violence is an action to target sexual desire like touching, groping, kissing, and/or other actions is not intended by the victims, to force to watch pornography products, sexual sayings is not intended by the victims, to force sexual relation without agreement of by the victims, with physical violence or not, and hurt or injuring the victims (Achie Sudiarti Luhulima, 2000 : 11-12). 
The problems of women with disabilities as the victims of sexual violence is an iceberg phenomena, where the cases are expressed is a little part of the many cases that are not found yet. Revealing the fact of cases of sexual violence against women with disabilities is not easy, because the violence which is happened hidden fact even it is hidden intentionally by the victims or the family. Based on the data is got from Center for Improving Qualified Activities in Live of People with Disabilities (CIQAL) Foundation Yogyakarta, since 2014 until 2016, CIQAL has noted there were seventy six of violence cases against women with disabilities in Yogyakarta region and sixty cases there are sexual violence. From the sixty cases of sexual violence only three cases have got law process, while other cases is handle by medical, psychology, economy, and mediation. It is not handled by legal cases is caused still low support and care from family and society to the victims, minimum understanding of law enforcement officer about disability, and the government is not able to do much overcome give service and colleague over all and continue to women with disabilities as the victims of sexual violence.

Actually based on the data are sufficient to indicate that the level of sexual violence against women with disabilities is high enough. The cases of increasingly of sexual violence happens now, proving that is still weak legal protection in cases of sexual violence in Indonesia. Concerning to women with disabilities as the victims of sexual violence at the present it is not as if of the important issues, many people do not think and want to do the concrete steps to protect people with disabilities rights.

The law which has provided is perfect basis to apply for the legal protection to women with disabilities as the victims of sexual violence. Article 5 Paragraph (1) point d The Law Number 8 of 2016 on People with Disabilities state that the women with disabilities have to get the protection more from violence include sexual violence. According to Prof. Dr. Barda Nawawi Arief, the protection of victims of crime can be seen two meaning, is protection of human rights or personal law interest it is means as the law protection not to become victims of crime, and the protection to get legal guarantee on the suffering that has become victims of crime is given with form of name recovery through rehabilitation, recovery of balance soul by forgiven, or giving compensation by restitution and charity of social welfare to the victims. 
Effort to protection and fulfill the rights of people with disabilities are one of the approaches to protect women with disabilities as the victims of sexual violence. In order to protect the rights of people with disabilities can be fulfilled, so that it is needed carrying out in harmony with the rules of law both of the government and social organization. A form of awareness of one of the social organization in responding to the issue of sexual violence against women with disabilities is like attempted by CIQAL which does carrying out of legal protection and fulfill the rights of people with disabilities. CIQAL is one of the organization concerns which cares the rights of people with disabilities is the first established by form of foundation in 2003 and is located in the city of Yogyakarta. CIQAL overcomes the sexual violence against women with disabilities cases and take a parts in order to give protection and colleague to women with disabilities as the victims of sexual violence both of legal, medical, psychological terms and so on. So CIQAL becomes the right place to do research about the forms of legal protection to women with disabilities as victims of sexual violence and to know obstacles that occur in the legal protection process.

\section{B. PROBLEM STATEMENT}

Based on the theme discussed above, this research would be focused on how the legal protection which is done by the CIQAL Foundation Yogyakarta to women with disabilities as victims of sexual violence and obstacles within process of legal protection to women with disabilities as victims of sexual violence that is done by the CIQAL Foundation Yogyakarta.

\section{RESEARCH METHOD}

The type of the research is an empirical legal research, is research conducted the law in reality in society and called primary data (Soerjono Soekanto, 2010: 51). Based on its character, the research is a descriptive research. Location of the research is at the CIQAL Foundation Yogyakarta. Type of data use the primary data and secondary data. Data collection techniques use through interviews and literature including regulations, research journals, and books relate to the problems that are studied. Technical data analysis use through qualitative analysis method to a model interactive. 


\section{DISCUSSION AND RESEACRH RESULTS}

\section{The Forms of Legal Protection which are Done by CIQAL Foundation Yogyakarta}

to Women With Disabilities as Victims of Sexual Violence

The view of the society of women with disabilities as someone who has boundaries, hopeless, and powerless, to become the opportunity for the perpetrators of violence who sees women with disabilities as victims is gullible. The perpetrators have significant relationship with the victims like their family (father), a close relative (uncle, cousin), neighbor, close friend, boyfriend, teacher, manager/leader. The party is supposed to safeguard and protect women with disabilities, precisely makes them an object of violence that make their situation getting worse. The issue of the violence against women (non-disabilities women although women with disabilities) is not a common crime. In its development, the violence against women (rape) is not only the juridical issue, but in relating to Human Rights, one of can ban their ability to participate fully in social activities and disturbing their health (Sabar Slamet, $2015: 3$ ). Many factors that encourage women with disabilities as victims of sexual violence such as unharmonious their family, lack of understanding of their family and society about the rights of people with disabilities, and lack of understanding of their family and society on the sexual violence issue. As follow is the data of sexual violence cases is noted by the CIQAL Foundation Yogyakarta since 2014 until 2016 in Yogyakarta:

Table 1.

Data of Sexual Violence in Yogyakarta

\begin{tabular}{|c|c|c|c|}
\hline \multirow{2}{*}{ Form of Sexual Violence } & \multicolumn{3}{|c|}{ Year } \\
\cline { 2 - 4 } & $\mathbf{2 0 1 4}$ & $\mathbf{2 0 1 5}$ & $\mathbf{2 0 1 6}$ \\
\hline Rape & 3 & 20 & 15 \\
\hline Rape and Sexual Exploitation & 0 & 0 & 3 \\
\hline Sexual Harassment & 0 & 0 & 3 \\
\hline Sexual Slavery & 0 & 1 & 0 \\
\hline
\end{tabular}




\begin{tabular}{|c|c|c|c|}
\hline Sexual Coercion & 0 & 0 & 1 \\
\hline Violence in Dating (KDP) & 1 & 9 & 5 \\
\hline $\begin{array}{c}\text { Harassment and Sexual } \\
\text { Exploitation }\end{array}$ & 0 & 0 & 1 \\
\hline
\end{tabular}

\section{Source : CIQAL Yogyakarta}

Based on the data, CIQAL is being paid attention and protect to the interests of women with disabilities as victims of sexual violence, is an absolute part that need to be implemented to give guarantee of the rise of humanity. Satjipto Rahardjo states about due to be broken of human rights by someone else, so the legal protection is needed to give supervision to human rights has been broken and the protection is given to society in order to fulfill all rights which is given by the law (Satjipto Rahardjo, 2000 : 53). Forms of the protection to victims of crime, according to Dikdik M. Arief Mansur and Elisatris Gultom can be given by restitution and compensation, counseling, medical assistance services, legal aid, and providing information (Dikdik M. Arief Mansur and Elisatris Gultom, 2007 : 166-172). In the concept of the legal protection to victims, contains legal principles is utility principle as an effort to minimize crime, justice principle as an effort to protect the victims, balanced principle as to restore balance in society, and principle legal certainty as based on the legal protection to victims (Dikdik M. Arief Mansur and Elisatris Gultom 2007 : 163-164).

$C R P D$ which has been ratified by Indonesia through Law Number 19 of 2011 on The Ratification of The Convention on the Rights of Person with Disabilities and The Law Number 8 of 2016 on People with Disabilities is the basis used by CIQAL to give concern and protection to people with disabilities in order to avoid any form of injustice, violence and discrimination in family, society, and state life. Article 26 of Law Number 8 of 2016 on People with Disabilities states that people with disabilities have the right to freedom and get protection from all forms of violence, including sexual violence. Besides that, Law Number 13 of 2006 jo. Law Number 31 of 2014 on The Protection of Witnesses and Victims is still valid and often used in legal protection for a witness and a victim who face the law. Article 2 states that "This Act gives protection to 
a witness and a victim in all level of the criminal justice process in the courts". The article means that everyone who becomes the witness and the victim are protected by the act, and without the difference condition of the witness and the victim who are people with disabilities, so protection against them at that time in criminal justice process is equal.

Concrete efforts by CIQAL to give legal protection to women with disabilities as victims of sexual violence is the legal colleague. The legal colleague is done with the system assists the victims intensively in solving their cases through the judicial process. Besides that, CIQAL also does the non -legal colleague or service to help the victims who overcome their cases through the non judicial process. The non-legal colleague consist of medical service, psychological service (counseling), mediation service, economy rehabilitation, shelter (safe house), and social reintegration service. For briefing to point out as follow:

a. The Legal Colleague

The legal protection is done by CIQAL to women with disabilities as the victims of sexual violence is the legal colleague. The goal from the legal colleague is to give the protection of the legal to the victims in overcoming their cases, to protect the victims rights, the victims get the colleague so they do not feel alone in overcoming their cases, the victims get a defense on theirs interest, in order to solve the sexual violence cases which happen their victims in accordance with the applicable law, and prosecute the perpetrators of sexual violence.

To give the legal colleague, CIQAL also cooperates with the Legal Centre 97 Yogyakarta, that provides the lawyers to give the legal aid free, and to assist women with disabilities as the victims of sexual violence in overcoming their cases through the judicial process. The legal colleague is done by the victim assistant and the lawyer with the system assists the victims intensively in the process of examination since the police until the court. The forms of legal colleague as follow:

1) To give information about the victims rights and service which are accessible to the victims, cover: 
a) The right to get protection with temporarily staying at the shelter (safe house). If the victims and their family intend to stay at the shelter, so the victim assistant is going to refer the victims to the shelter own The Empowerment Services for Women and Children (P2TP2A) Sleman;

b) The right to get health service is care and treat medical check up according to the victims medical needs. In the matter, the victims assistant is going to refer the victims to the hospital in Yogyakarta to care and treat medical check up to get the violence description, healing of the victims, recovery or therapy of the victims, and get the written report of medical results/Visum et Repertum or the medical notes that have the legal as evidence in court.

c) The right to get psychological service (counseling) to strengthen and give safety to the victims;

d) The right to get special overcoming (according to disabilities condition) and the confidentiality of the victims.

2) To give understanding to the victims and their family about the legal steps process is going to faced;

3) To carry out colleague to the victims since in the police until the court process;

4) To give information and monitoring about the cases progress legally.

The victim colleague since in the police until the court process, is carried out by the victim assistant with mechanism as follow:

1) Cases Investigation

a) Cases notes, including the identity of the victim, the identity of the perpetrator, the relationship between the victim and the perpetrator, incident of violence location, period of violence incident, types of violence, and incident narration which is explained detail including depend the background of the victim and the perpetrator;

b) The problem inventory, helps to collect the written evidence, and the witnesses, and other evidence.

2) The Victim Colleague at The Police 
The colleague is done by the victim assistant to accompany and help the victims at the time of reporting cases to the police, to assist the victims at the time asked for the question on the BAP process and help to prepare of evidence and witnesses. The first victim assistance and victim and victim family come to The Unit of Women and Children Protection (UUPA) Local Police/Head Quarter Police, if it is clearly an element of the criminal will be carried on to Sentra Special Reports (SPK) it is made up the reports and the cases reporter get a Letter of Reporting (STPL) then carried on to the BAP process at UUPA Local Police/Head Quarter Police. At the time of the victim colleague in the BAP processing, the victim assistant is usually going to prepare a translator who understands the language of people with disabilities, so that what the victims expresses can be understood by the investigators. Before presenting the translator, the victim assistant is going to coordinate with the investigators to get license to present the translator.

In doing the colleague in the police, the victim assistant helps and guides the victims to:
a) State true about the happened cases;
b) Give the chronology of the true cases;
c) If there is a threat or violence must be expressed.

3) The Victim Colleague at The Court

Victim colleague in processing of examination at the court, is done by the victim assistant and the lawyer with the way accompany by the victims to help explaining the victims cases objectively and completely. Besides that the colleague is done to give law consultation cover the information of the victims rights and court process is going to be done by the victims, and to do coordination with other law enforcement, the victim assistant, and other institution.

After finishing the judicial process, it means after there is a court ruling with permanent legal force (inkracht van gewijsde), in recovering the victims, CIQAL does some process, but the matter is depended on the victim intention, as follow:

1) Trauma Healing 
Post judicial process, the victim assistant is not going to break with the victims, because it is the most important thing of the victim assistant role as the person who is trusted by the victims, sharing, and look for good solution, so it is needed by the recovering the victims.

2) Psychological Counseling

Psychological counseling is given to the victims which goal to give mentally and psychological strength on the violence happen to the victims and to motivate the victims to make synergizing an accepting the real condition. Women with disabilities as the victims of sexual violence are often called down verbally by society causes they feel marginalizing, therefore CIQAL participates to give support to the victims in order to be confident and can communicate in their environment.

3) Economical Activity

The victims can be develop their skills that is owned, it means to be self confident to fulfill their need, giving the skill full training in economic field. The matter is as a good support to the victims to continue their live.

b. The Non-Legal Colleague

In addition to the legal colleague to the victims who overcome their cases through the legal process, CIQAL in this case also has done the non-legal colleague or services to help the victims who overcome their cases through the non judicial process. The non-legal colleague who has done by CIQAL to the women with disabilities as the victims of sexual violence is the way to assist the victims in access the non-legal services (medical service, psychological service (counseling), mediation service, economy rehabilitation, shelter (safe house), and social reintegration service). The non-legal colleague is done when the victims or their family purposes their cases is done by the non judicial process. However the nonlegal services, as follow:

1) Medical Service

On providing the medical service, CIQAL is going to refer the victims to the hospital in Yogyakarta such as Grhasia Hospital, Dr. Sardjito Hospital, Kartika Husada Maternity Hospital, Public Hospital Wates Kulonprogro 
Yogyakarta, and other hospital can access the medical services. A medical checking to the victims of sexual violence means to get the violence description, healing of the victims, recovery or therapy of the victims, maternity service if the victims have a pregnancy.

2) Psychological Service (Counseling)

Psychological services for women with disabilities as the victims of sexual violence are given as assistance of psychological reinforcement to the victims to eliminate the trauma which is happened and to give safety for the victims. Psychological services which is given by CIQAL like counseling is done by involve a psychologist/psychiatrist or without them, listening to the victims tell about their case and need is required by the victims.

3) Mediation Service

Mediation service is the resolving of sexual violence cases is done outside of the judicial process, or a family based on protection justice principle, non-discrimination, and the best interests for the victims. The implementation of mediation is done by CIQAL cooperating with collaboration with The Empowerment Services for Women and Children (P2TP2A) which is done at the victim house with involving related parties such as the victim, victim family, the perpetrator, perpetrator family, RT leader, society leader, victim neighbors, and others, it is aimed to achieve agreement and the peace between the perpetrator and the victim.

4) Shelter (Safe House)

Safe house is the temporary house is occupied by the victims of sexual violence that the victims feel safe from the violent perpetrator. The victims also will be given the colleague is counseling to strengthen psychology, the medical service to overcome and recover the victims conditions. On providing safe house, CIQAL cooperates with The Empowerment Services for Women and Children (P2TP2A) Sleman, because CIQAL does not have the safe house for the victims of sexual violence. When the victims intent to be placed in a safe house, so CIQAL refers the victims to P2TP2A. However, not all the victims 
can not stay in the safe house, because P2TP2A is going to see the urgency of the victims case.

5) Economical Rehabilitation

Economical rehabilitation, CIQAL is going to refer the victims to The Integrated Rehabilitation Center for People with Disabilities (BRTPD) Pundong Social Duty Yogyakarta. Economical activity is meant to the victims can be develop their skills that is owned, and giving the tools that support their victims skill to afford doing their business.

6) Social Reintegration Service

The social reintegration it is meant as a process to prepare society to support the reintegration of the victims into the society environment and their family environment, which can give the protection and fulfillment of the victims needs. The social reintegration is done by socializing about sexual violence issue and the rights of people with disabilities, to give motivation and support to society at the victims' area. The matter goals in accordance the society does not do marginalizing the victims and give the support to the victims not to go down on their cases. Besides that is also done motivating to the victims intend the victims can recover their self confident and can interact in their environment without fear. The matter people with disabilities have the rights of socialization and interact in their family, society, and state life without fear (Article 26 point a The Law Number 8 of 2016 on People with Disabilities).

\section{The Obstacles within Process of Legal Protection to Women with Disabilities as Victims of Sexual Violence that is done by CIQAL Foundation Yogyakarta}

Based on research at CIQAL, on doing the colleague to women with disabilities as victims of sexual violence there are some factors that become the victims obstacle in getting their rights, as follow:

a. Internal Victims Factors

1) Limitation which Owned The Victims

a) The Victims Communication 
The problem that is faced the victims assistant to overcome the sexual violence cases to women with disabilities is communication problem of the victims especially the people with intellectual, deaf, and blind. The victims assistant is often difficult to understand the information when communicating to the victims, so to understand what the victims express must use a translator who understand the victims' language.

The problem of difficult communication on the victims, it influences the law process where the law enforcements do not understand how to communicate to the victims of disability, even though in the law process is needed the evidence must be applied for the BAP is made by the police. It is often in overcoming the cases, the victims is considered inconsistently to express the violence cases that happened it causes the victims testimony it is concluded by the law enforcements that the victims has been lain and the violence cases never happen.

b) The Victims Age (it is not suitable between calendar age and mental age)

Incompatibility between calendar age and mental age of the victims, it is often the victims have already been adult but mental victims is not adult yet. For example, when the victims get experience sexual violence, calendar age of the victims has been 21 years old, and the mental age of the victims as the result of psychological assessment is still 10 years old. Based on the mental age of the victims actually the victims is still children category which is often the victims get trauma on the investigating phase of adult procedure. The condition like this, sometimes the victims are difficult to memorize the incident has been happened, so it causes their testimony is made doubtful by law enforcement officers. The matter is the same as the interview result (March 21, 2017) with Mr. Ibnu Sukoco, S.H. as Coordinator of the Economical Empowerment Division, which states that "mental age of people with disabilities and calendar age of people with disabilities when the sexual violence cases happen must be differentiated in the law area. However, in reality, behaving of the legal 
between the victims of normal condition and the victims of disable condition are equal".

2) The Victims Family

At the time women with disabilities become the victim of sexual violence, often their families do not understand that there has been violence against their family. Most of their family, require the sexual violence cases which is happened not to process in the law by the reason is embarrassed, difficult, and pessimistic to get the justice. The victims family do not know the rights that is belonged to either rights as people with disabilities or rights as the victim. There is embarrassed feeling that is felt by the victims family because the perpetrator is close person of the victim makes the family cover the cases in order to not to be known by the society and afraid of as if they can not protect and educate their child.

Feelings of shame that the families of the victims because the author is the closest family coverage of the victim has done the case that is not known in the community because he considers the case a shame for The family and the fear of being unable to protect and educate a child.

b. External Victims Factors

1) Problems in the Legal Scope

a) The Collection of Evidence

Taking and collecting the evidence in the case is a great of influence in the conclusion. In the sexual violence cases, the investigators are going to seek the evidence as much as possible to support disclosure of the case. However, the investigators cannot often find out and collect the to evidence because of the lack of evidence because the perpetrators have been deleted the traces of violence that has been done which cause of the disclosure cases very complicated.

b) Understanding of the Law Enforcement Officers

There is no special conduct mechanism to overcome to sexual violence especially that happened to the women with disabilities, makes the law enforcement officers do not understand how to handle the case. 
Understanding the law enforcement officers to violence cases does not take sides to women as victims. The law enforcement officers have assumption that the violence to women is only a physical matter, is not understood that violence to women also can happen non physically, is physically, social and cultural, economic and politic (Nur Rochaety, 2014 : 7).

The handling of the sexual violence cases without there is the special conduct precisely disposed will defend the discrimination to women with disabilities as victims of sexual violence and is not able to get justice. The special conduct it is meant that the law enforcement officers to concern the different ability which is owned by people with disabilities, because the only with the special conduct can be reached the conduct in protection and fulfillment of the rights of people with disabilities. The law enforcement officers usually get the only the guidelines by the positive law and do not use other approaches on the limitations that is owned by the victims with disability, so it can be said the law enforcement officers have no perspective yet about the disabilities.

At the present the law enforcement officers only focus to the articles that the fact is unfamiliar to the rights of people with disabilities that dealing with the law. The matter regards with Muhammad Taufiq's statement that states many the law enforcement officers reduce understanding that enforces the law is meant equal with enforces the regulations or referring to the formal regulation. Cause of the court system in Indonesia is not a little verdicts is far from the society dynamic (Muhammad Taufiq, 2013 : 4). The effect is not understood by the law enforcement officers of disability, cause the law enforcement officers do not overcome sexual violence cases that is happened by the victims fairly, so it happens violating the human rights to people with disabilities. Violating the human rights indirectly is the abandonment to the legal cases that happen to people with disabilities. Such as the condition makes people 
with disabilities look like have been as the victim intentionally and it is not facilitated their rights on equality before the law.

2) Society

Society still feel unsafe when there is one of members of the their society who become the victims of the sexual violence known by the outsiders. The society assumes the people with disabilities as the group which is not too important to be concerned, so if it happens sexual violence to women with disabilities tend to lack of concerned. The society does not understand rightly yet that the violence that happens in the society is the criminal act that violates the human rights. Perception of the society about the violence to women is "normally", so there are many people do not report and are reluctant to report.

\section{E. CLOSING}

\section{Conclusion}

a. Based on the research result and study that has been explained, generally it can be concluded that there has been a legal protection of women with disabilities as the victims of sexual violence is given by CIQAL, however there are some notes. The forms of legal protection, as follow:

1) The Legal Colleague

The form of legal colleague to women with disabilities as the victims of sexual violence is done by CIQAL as follow:

a) To give information about victim rights and services which are accessible to the victims;

b) To give understanding to the victims and their family about the legal steps process is going to faced;

c) To carry out colleague to the victims since in the police until the court process, cover:

(1) Cases investigation;

(2) The victims colleague at the police;

(3) The victims colleague at the court.

d) To give information and monitoring about the cases progress legally. 
In addition to the legal colleague to the victims who overcome their cases through the legal process, CIQAL in this case also has done the non-legal colleague or services to help the victims who overcome their cases through the non legal process. The non-legal colleague, as follow:
a) Medical Service;
b) Psychological Service (Counseling);
c) Mediation Service;
d) Shelter (Safe House);
e) Economical Rehabilitation;
f) Social Reintegration Service.

b. The obstacles which are got by CIQAL within giving the legal protection to women with disabilities as victims of sexual violence, as follow:

1) Internal Victims Factors

a) Limitation which owned the victims, cover:

(1) The victims communication;

(2) The victims age (it is not suitable between calendar age and mental age).

b) The victims family.

2) External Victims Factors

a) Problems in the Legal Scope, cover:

(1) The collection of evidence;

(2) Understanding of the law enforcement officers.

b) Society.

\section{Suggestion}

a. Effort to implementation fulfillment the rights of people with disabilities are not easy matters, are needed intentionally from the parties in order to the matters can be overcome very well. The state in this case has obligation to take guarantee and organize clearly about the protection to people with disabilities which face with the law, moreover to women with disabilities as the victims of violence. The matters mean special overcoming and protecting to people with disabilities which face with 
the law, must be guaranteed and written on the regulations which in implementing the justice which has disability and human rights perspective.

b. It is necessary to understand very much about disability for the legal enforcement officers on overcoming the violence to women with disabilities cases to guarantee the rights of victims on the truth and the justice, and it must not be repeated of the violence again to the victims by the perpetrators.

\section{BIBLIOGRAPHY:}

\section{Books and Journals:}

Achie Sudiarti Luhulima, 2000, Pemahaman Bentuk-Bentuk Tindak Kekerasan terhadap Perempuan Perempuan dan Alternatif Pemecahannya, Bandung: P.T. Alumni.

Barda Nawawi Arief, 2014, Masalah Penegakan Hukum dan Kebijakan Hukum Pidana dalam Penanggulangan Kejahatan, Jakarta: Kencana Prenamedia Group.

Dikdik M. Arief Mansur dan Elisatris Gultom, 2007, Urgensi Perlindungan Korban Kejahatan Kejahatan Antara Norma dan Realita, Jakarta: PT RajaGrafindo Persada.

Muhammad Taufiq, 2013, "Penyelesaian Perkara Pidana yang Berkeadilan Subtansial". Yustisia. Volume 2 Number 1.

Nur Rochaety, 2014, "Menegakkan HAM Melalui Perlindungan Hukum bagi Perempuan Korban Kekerasan di Indonesia”. Palastren. Volume 4 Number 1.

Sabar Slamet, 2015, "Politik Hukum Pidana dalam Kejahatan Perkosaan”. Yustisia. Volume 4 Number 2.

Satjipto Rahardjo, 2000, Ilmu Hukum, Bandung: PT. Citra Aditya Bakti.

Soerjono Soekanto, 2010, Pengantar Penelitian Hukum, Jakarta: Univ. Indonesia (UI-Press).

\section{Regulations:}

The 1945 Constitution of The Republic of Indonesia.

Law Number 19 of 2011 on The Ratification of Convention on The Rights of Persons with Disabilities.

Law Number 13 of 2006 jo. Law Number 31 of 2014 on on The Protection of Witnesses and Victims. 
Law Number 8 of 2016 on People with Disabilities. 